\title{
IDENTIFICATION OF A NEIGHBOUR (LUKE 10:25-37) IN NIGERIAN MULTI-CULTURAL CONTEXT
}

\author{
Anthony I. Ezeogamba \\ Anambra State University (ANSU), Igbariam Campus \\ revtonyiyke@yahoo.com
}

\section{Preamble}

The story of the Good Samaritan is one of the ways through which Christ emphasizes that we ought to look at one another fundamentally as image and likeness of God. The presence among Christians of tribal sentiments and loyalty to one's ethnic group must be a scandal of great proportion to all of us who claim to be the agents for spreading Christ's kingdom of love, and brotherhood in the world. Since we are now the authentic image of God, there ought not to be any form of division among us.

Reading Pauline letters reveal that humanity is divided into two major groups namely Jews and Gentiles (Rom 3:29-30; Gal $2: 11-21 ; 3: 26-29)$. This fact is also identified even in the Gospels. Within these major groups there are sub-divisions. There are also the Jews and Samaritans as opposing groups, there are circumcision party (Gal 2:12) and uncircumcision party. Among the Jews we have also the priests, and Levites who take care of worship. Members of each group look at themselves as neighbours and never neighbour to those outside their group. Because of class bias, there is injustice and disregard for others.

In Nigerian society we have such factions, which range from religious faction to ethnic or cultural factions. Even among people of the same religious groups there are also discriminations of one kind or the other. The neighbourly care depends on which faction you belong. Jesus in his radical sayings and actions 
suggested that he proclaimed a kingdom that embraces men and women rather than Jew and Gentile, Hausa or Yoruba, Igbo or Ibibio, etc (Mark 11:15, Luke 10:30-35).

The aim of this study is to know whether we can use the Samaritan story (Luke 10:25-37) as was used by Jesus to solve the problem of 'who is my neighbour,' cultural, tribal or ethnic bickering and religious riots in Nigeria. It is believed that after following this paper, one will be able to turn the search light of discernment within our own various lives. Finally we ought to transcend our various cultures just as the Good Samaritan did (Luke 10:25-32), also as Ruth and Boaz did (Ruth 2:11-12;4:1).'

\section{Definition of Terms:}

\section{Good Samaritan}

The question is: who is a Samaritan and what is 'Good' about him? "Samaria" is originally a Greek name. The capital of the Northern kingdom, established by Omri about 880 (1 Kgs 16:24). It gave its name to the surrounding environs (Luke 17:11; John $4: 4-5$; Acts $8: 1-8$ ). After the deportation of $722 \mathrm{BC}$, its population was a mixture of races $(2 \mathrm{kgs} 17: 5-6,24)$ it was destroyed in 108 B.C; it was renovated in $30 \mathrm{BC}$ with the name Sebaste. Because of that mixture of races, in the first century the Samaritans were treated as heretics, legally impure (Luke 9:52, John $4: 9 ; 8: 48)$. In Luke 9:52-56 there is a typical case of discrimination; such is also noticed in John 4: 9 . The Jews called them "halfbreeds." ${ }^{2}$ The Samaritans because of the above information are rarely called "Good." For the Jews, they are always "Bad." The Oxford Dictionary of Christian Church, defines the Good Samaritan thus, "He is the Samaritan of the

'Shores, L. Willaim D. Halsey et al (ed) (1974) Collier's Encyclopaedia with Bibliography and Index, vol.7, Canada: Macmillan Educational Corporation, 554. ${ }^{2}$ Bultmann, A. R. (1964) Theological Dictionary of New Testament vol. viii. Gerhard Kittel (ed.) Michigan: WMB Eerdmans Publication, 359. 
parable in Luke 10:25-37 who, in contrast to the priest and Levite who 'passed by on the other side', tended the traveller who had fallen among thieves on his way from Jerusalem to Jericho and provided hospitality for him at an inn. His actions illustrate the Christian response to the question: who is my neighbour (Luke 10:29)?"3 One can rightly say that a Good Samaritan is one who has distinguished himself/herself from his/her cultural and religious background and embraces the real spirit of Christ in words and deeds. ,

\section{Multi-Culture}

If one understands the meaning of culture then the meaning of 'multi' can easily be inferred. As far as definition of culture is concerned no single definition has yet won universal acceptance. This write up shall then choose the ones that will throw light on the topic under study. The biologist Paul Sears writes that culture is, "The way in which the people in any group do things, make and use tools, get along with one another and with other groups, the words they use, and the way they use them to express thoughts, and the thoughts they think." For Edward B. Taylor "Culture ... is that complex whole which includes knowledge, belief, art, law, morals, custom, and any other capabilities and habits acquired by man as member of society." What is very clear from the above is that culture is learned rather than transmitted by the genes, which pass on biological inheritance from the two parents.

Nigeria as a multi-cultural state indicates there are many cultures in Nigeria. The implication is that the way Hausa man

${ }^{3}$ Cross, F.L. Ed et all. (1978)The Oxford Dictionary of the Christian Church, 2nd Ed. Britain: Oxford Uni. Press, 580.

${ }^{4}$ Shores, L.William D. Halsey (1996) ed. et al. 555.

'Shores, L.William D. Hạlsey (1996) ed. et al. 555. 
Saरtsfies his/her basic needs is different from the way a Yoruba will satisfy his own. The way each cultural group relates to other groups outside them is what the young learns from the e'ders, which is transmitted from generation to generation. So if one gets an Hausa child, and brings it up among Igbos, it will have Igbo mentality or way of looking at reality.

\section{The Text of Luke 10:25-37 in Lucan Context: The Background of the Gospel}

According to Irenaeus of the 2nd century, AntiMarcionite Prologue (c 160-180); the Muratorian Canon also of 2 nd century, $\delta$ t. Jerome and others state that Luke is the author of the Third Gospel. Luke wrote it in the region of Achaia. Though 'sefore him, some gospels had been written, yet it was still necessary to present to the faithful converted from paganism an exact account of the economy of salvation history lest they stray from the truth by the deceit of heretics (Luke 1:1-4).

Luke wrote his gospel for Gentile Christians. Hence he conveniently avoids matters, which appear too specifically Jewish. Such include: the traditions of the ancients (Mark 7:1$23)$; the return of Elijah; ${ }^{6}$ he emphasized those that upheld the Gentiie interest (Luke 10:25-37). Luke's may have been written between 80 and $85 \mathrm{AD}$, but the exact date of the Gospel, is hardly a vital question.

\section{Delimitation of the Text}

Luke 10:35-37 is one central unit with two parallel parts. Part one is verses $25-28$ which starts with the question of the lawyer (.v 25) and ends with Jesus' command (v 28). Part two (2937 ) also starts with lawyer's questions (v 29) and ends with Jesus

${ }^{6}$ Harrington, W.J. (1967) The Gospel according to St. Luke: A Commentary, Westminster, Md: Newman press,3-5. 
command ( $v 37 b)$. It is a unit because what took from verse 25 is concluded in verse 37 , all dealing on one theme- identification of who should be my neighbour.

\section{The Remote Context}

The parable of the Good Samaritan falls within the journey of Jesus to Jerusalem (9:51-19:27). Throughout these chapters Jesus is presented as a wondering teacher. The divine intention of Jesus' mission is to go toward suffering; the demand of discipleship is to follow. For instance in 9:51.62 he deals with the cost of discipleship, in 10:1-24 he deals with the mission of the seventy, then in 10:25-37 he deals with eternal life and the neighbour.

\section{The Immediate Context}

Since Jesus has spoken of revelation of the kingdom, an expert in the law tries to put him to the test by his question ( $v 25)$. So when the lawyer had given the right answer (v 27) as was demanded by Christ, Jesus admonished him to do the same ( $\mathrm{v}$ 28). So in order to justify himself or to find some way to escape the demands of the law, the lawyer then raises a question of: Who is my neighbour (V 29)? Hence the parable of the Good Samaritan (vv 30-37) is an answer to his question. The question of the lawyer is the immediate context of the parable.

\section{Content Analysis of Luke 10:25-37}

The story of the Good Samaritan (vv 25-37) deals with the meaning of the commandment to love one's neighbour as oneself (V 27b). According to J.D. Crossan, the form of 10:25-37 is that of a "controversy dialogue" with two parallel parts. Part One: Verses 25-28 has four components: (1) the lawyer's question (V $25)$; (2) Jesus' counter question ( $\mathrm{v} 26)$; (3) the lawyer's own answer (v27) and (4) Jesus' command (v 28). Part Two: verses 
29-37, has also the same four components: (1) the lawyer's question (v29); (2) Jesus' answer and counter-question (vv 30$36)$; (3) the lawyer's own answer (v 37a); and (4) Jesus' command (v 37b). The two parts, verses 25-28; and verses 29-37 are held together by the key words "piesion" (neighbour) (vv 27,36) and "Poiel" (do) (vv 25, 28,36).

When one looks at the other synoptic gospels (Matt 22:2831) one discovers that Luke like Matthew says that Jesus' opponent was a lawyer, that he only came to test Jesus, and he addressed Jesus as a Teacher. For Luke alone, the question is about how to inherit eternal life (cf. 18:18). In Luke alone also Jesus asks the lawyer, "What is written in the law? How do you read?" That is the counter question. Luke alone has the lawyer giving the answer himself (v 27) and not Jesus as the other synoptic gospel writers would want us to accept. Finally, only in Luke does Jesus respond with an appraisal and a command: "You have answered right; do this and you will live" (V28). It is this appraisal and command of Jesus that really captured our interest and to posit that if one accepts the command of Jesus, then, there will be peace everywhere.

\section{The Test Question}

Though the lawyer that questioned Jesus is attested by Luke as merely testing him, anyone who reads between the lines of 10:25-37 will discover that the man was deep in his cultural bias. Though he came out to test, but his ignorance and background was exposed and punctured. This idea is fully captured by Charles Talbert hence he writes,

Since it is two Jews talking and since it was assumed by Jews that the people of God would inherit the New Age, the import of the question is clear. The lawyer is asking what he, as an 
individual should do to guarantee his place in the people of God who would inherit eternal life: "What do I do to belong to God's people?" Moreover, when the lawyer asks, "who is my neighbour?" he wants to know how he can spot others who belong to God's covenant people. The Jews interpreted "neighbour" in terms of members of the same people or religions community; that is, fellow Jews. Even within the Jewish people there was a tendency to exclude certain others from the sphere of neighbour... Jews generally excluded Samaritans and foreigners from the category of neighbour.

Already the lawyer has a myopic idea of who a neighbour should be and Jesus was aware of the lawyer's background and motivations. Jews believed that they were the only known "people of God," hence the only people that would be saved. They assume to be the only sons and daughters of Abraham; others were not.

Jesus knew all these; that is why after replying to the question of verse 29 with the parable (vv 30-35), he concluded with another question ( $v 36$ ). When the lawyer answered back in verse 37 a, Jesus retorted with present infinitive "Poreuou kai su poiei homoios" (Go and do likewise) which means, cast away the old idea you have, the ethnic bias, cultural impediments, the old Yoke and put on a new garment of salvation, a new approach to life.

'Talbert, C. (1982). Reading Luke, A Literary and Theological Commentary on the Third Gospel. New York: Cross Road, 121. 
According to Harrington "the lawyer's trap question, "who is my neighbour" ( $\mathrm{v} 29$ ) as taken up by Jesus ( $\mathrm{v} 30$ ) and turned it back on his opponent is one of the most beautiful of all the Gospel parables, the moral tale of the compassionate Samaritan $(10: 30-35){ }^{8}$ So to test Jesus is to expose one's ignorance, and to realize that one has been standing on a slippery ground.

\section{The Self-Justification Question}

The lawyer looked at himself as one who had loved his neighbour well all these years. So in order to tell Jesus that he was already part of the kingdom and bearing in mind Lev. 19:18, 3334 , he asked, "Who is my neighbour?"'(V.29). After the parable, it is clear that both the lawyer and some Jewish audience must have left the scene with the shock of their lives. Because for them if love for neighbour meant anything, it meant to care for the sons and daughters of one's own clan, but Jesus made them to know that it was all embracing. They must have been confused when they realized that the Samaritan understood 'neighbourliness' more than they did. Let us conclude this section with Harrington who says,

The point, we learn is not who deserves to be cared for, but rather the demand to become a person who treats everyone encountered, however frightening, alien, naked or defenceless with compassion: 'you go and do the same'. Jesus does not clarify a point of law, but transmitted law to gospel. One must take the same risks with one's life and possessions

${ }^{8}$ Harrington, D. (ed.) (1991).The Gospel of Luke: Sacra Pagina, vol. 3, Minnesota:
The Liturgical Press, 175. 
as the Samaritan did. ${ }^{9}$

Whenever one is claiming perfection one should know that all is found wanting in the face of divinity.

\section{Jesus' Reply (Vv 29-35)}

Jesus' reply proves to us that at the end of our earthly existence, we shall neither be judged wrong nor right because we came from this ethnic group or that, nor shall we be judged by the creed we held while alive but by the way we lived our lives. According to Barclay, Jesus' reply involves three things:

(I) We must help a man even when he has brought his trouble on himself, as the traveller had done (II) Any man of any nation who is in need is our neighbour. Our help must be as wide as the love of God. (III) The help must be practical and not consist merely in feeling sorry.... What Jesus said to the scribe, he says to us - 'Go and do the same., ${ }^{10}$

The reply of Jesus is summarized as knowing what is good and acting according to that. One ought to help anyone, any human person in need as much as one can bearing in mind that that person is an image and likeness of God. It is clear to us that those who passed that wounded man were ethnically biased, and can be called religious imbeciles!"

For Jesus, such a way of approaching one's fellow human being

${ }^{9}$ Harrington, D. J. (ed.) (1991). 175.

${ }^{10}$ Barclay, W. (1987). Gospel of Luke: The Daily Study Bible, Edinburgh: The Saint Andrew Press, 140-141.

"Knowles, M. (2004). "What was the Victim Wearing? Literary, Economic and Social Contexts for the parable of Good Samaritan" 170. 
because of earthly bias is not worthy of those who follow him. We can rightly say that Jesus' answer to the question put forward by the lawyer is provided in the story of the Good Samaritan. A neighbour is anyone in need with whom one comes into contact and to whom one can show pity and kindness, even beyond the bounds of one's own ethnic or religious group.

\section{The Traveller}

The passage did not tell so much about the nationality of the traveller. But what is very clear is that the passer-by could infer from which tribe he hails from i.e. whether a Jew or Gentile. ${ }^{12}$ If almost everything about him is under speculation we can say without mincing words that there is a lack of clarity on the victim's ethnicity (Luke 10:25-37) which underscores the point, the Samaritan of the parable does not bother with such distinctions instead he was moved with pity (v 33) (esplagxnisthe) and acted accordingly. Hence, Jesus proposes an ethic that is determined neither in relation to the shared codes of social stratification nor in relation to membership within a particular group, but solely on the basis of an internalized ethical orientation. Jesus in that parable intentionally left the man undesirable, which means he could be any man, although a Jewish audience would naturally think of him as a Jew, by considering the man's movement (Jerusalem to Jericho v 30 ). So Jesus really wanted to talk of the man as "adam" or "anthropos" as was created by God and as image of God, a human person "anthropos" without any article (a certain man, a man). Love and care should be universal. Barclay describes the traveller thus: "He was obviously a reckless and foolhardy character. People seldom attempted the Jerusalem to Jericho road alone if they were carrying goods or valuables. Seeking

${ }^{12}$ See Section 3.5 for more information as Michael Knowless posited. 
safety in neighbours, they travelled in convoys or caravans. This one had no one but hims alf to blame for the plight in which he found himself"."

From the above, the road from Jerusalem to Jericho was a notoriously dangerous one. For Barclay it was a road of narrow, rocky defiles, and of sudden turning which made it the happy hunting-ground of brigands. ${ }^{14}$ Each of us in one way or the other, sometimes put ourselves in a situation in which we can't redeem ourselves. Jesus says when we see one another in such predicament we should not hesitate to offer solution.

\section{The Priest}

According to Harper's Bible Dictionary (1994) the priests are "the specially designated officials who served in the temple performing ritual functions and conducting the sacrificial services." The Hebrew word "Kohen" designates not only Jewish priests but also those who served in temples dedicated to other gods. Harper makes it clear also that "there is no feminine form of 'Kohen,' 'Bat Kohen' (daughter of a priest) refers to a woman of a priestly family." According to Deuteronomy, all the Levitical families had a right to the priesthood since they did not receive an inheritance of land like the other tribes (Deut. 10:8-9). Aaron and his sons exclusively received the anointing oil and were attired in special clothing of the priesthood (Exod. 28-29, cf Isa. 14:3, Ezek. 40:46, 44:15-16, Amos 7:10-17).

There are ordinary priests and also high priests depending on the

\footnotetext{
${ }^{13}$ Barclay, W. (1975) The Gospel of Luke: The Daily Study Bible, 139.

${ }^{14}$ Barclay, W. (1975). 138.
} 
type of sacrifice that is involved. There are Aaronide priests; those that descended from the first acclaimed priest (Exod. 2829), and also Levitical priests, those that descended from Levi (1 Sam 14:3, Ezek. 40:46, Amos 7:10-17). The functions assigned to the priests are listed in Lev. 12,13,15. And for a priest to be able to carry out those responsibilities worthily, he must always be ritually pure/clean. Hence, Barclay, ostensibly sympathetic of the priest's and Levite's predicaments, says after the mind of Christ.

The priest hastened past. No doubt he was remembering that he who touched a dead man was unclean for seven days (Num 19:11). He could not be sure but he feared that the man was dead; to touch him would mean losing his turn of duty in the temple and he refused to risk that. He set the claims of ceremonial above those of charity. The temple and its liturgy meant more to him than the pain of man. ${ }^{15}$

That reminds us of Jesus' statement: "The Sabbath was made for humankind, not humankind for the Sabbath" (Mark 2:27). Paul would echo, 'anything one does that is not motivated out of love of God and neighbour, one wastes his or her time' (I Cor. 13:113)). By mentioning priest and Levite as one of the passers-by, Jesus really meant to attack ritualism, which prevents acts of love (v 31). The attack of Jesus was really on the failure to show love: whatever the pretext.

\section{The Levi}

"Barclay, W. (1975). 139. 
The Hebrew word "Lee'vi" 'joined'. Levi is the third son of Jacob (Gen 29:34), the tribe descended from the third son of Jacob. He is from Jacob's wife Leah (Gen 35:23). ${ }^{16}$ Nowhere in the OT is Levi given any allocation of territory (Josh 13:1-19). On the contrary, it is said that her members have no share in the land, because they have been chosen by God to serve him as priests (Josh 18:7). All we know is that both Priests and Levites are involved in activities of the temple. In some places they appear as solely priests whose function was not only sacrificial but also to transmit and administer the divine law (Deut. 17:18, 33:10; Josh 21 1-42).

However, it would seem that the Jerusalem authorities would not accept the Levites as true priests and they were reduced to a subordinate position in the cultic staff ( $2 \mathrm{kgs} 23: 8-9)$... They alone may carry the Ark, the Temple's holiest object (1Chr 15:11-15). In addition, they provided the music for the services (1Chr 16:1437)... They retained their ancient functions of administering the law (1Chr 23:4; $2 \mathrm{Chr} 19: 8-11)$ and of teaching it to the people (2Chr 17:7-9; $35: 3)$; many of the speeches in 1 and 2 Chronicles may reflect the form of contemporary Levitical sermons. ${ }^{17}$.

We can see the great reason behind Jesus mentioning priests and Levites among those who saw the man and went their way. In actual fact they were supposed to lead others by example but

${ }^{16}$ Cf.Achtemeier, P.J. ed et al (1994) Harper's Bible Dictionary, India, Bangalore: Theological Publications, 557.

'Bultmann, AR. (1964) Theological Dictionary of New Testament vol. viii, 359. 
Identification Of A Neighbour (luke 10:25-37)In Nigerian...

instead the "despised Samaritan" whose ethnic name the lawy could not even pronounce (v37), turned out to be the one th: leads.

\section{The Samaritan}

inhabitants as (1kgs 16:32); Samaria is associated with the false worship a Bethel (Amos 3:14-15; Hos 8:6; 10:5-7). Its fall was connectec with idolatry (Isa 8:3-4; 10:9-11; Amos 8:14; Micah 1:5-7). The inhabitants of Samaria are likewise called arrogant (Isa 9:8-17 and people full of evil deeds and rebellion (Hos 7:1-7; 13:16).

Samaria faced a lot of misdirection from the hands of Assyrians and that exactly led to the confusion found among them and the subsequent hatred. It was once part of Assyria (721-612 BCE) and also part of Persia (39-322 BCE), we know that these are foreign countries with different gods. They influenced Samaritans so much. The Assyrians brought in foreign colonists among them and deported much of the natives, others even fled to Judea. "A heterodox Yahwism based on the Pentateuch and influenced by other religions soon developed (2kgs 17:24-41;2Chr 30:1-9), and provoked Jewish antiparty."

Samaritans are generally noted for good deeds especially when it hurts. We can see example of that in OT. There is one case of even better behaviour, since it is mercy and kindness shown to beaten attackers (2Chron.28: 9-15; 1kings 13:11-34). They really acted again like the Samaritan mentioned in Luke 10:25-237. In John's gospel they asked Jesus to stay with them

${ }^{18}$ Cf Stuhlmueller, C. (1996), The Collegeville Pastoral Dictionary of Biblical
Theology. Minnesota: The Liturgical Press, 872 .
'O'toole, K.F. (1996) "Samaria| Samaritan" in Stuhlmueller, C. (1996) The
Collegeville Pastoral Dictionary of Biblical Theology. Minnesota: The Liturgical
Press. 872-75. 
(John 4:40). That shows that they were generally kind hearted. They are very appreciative (Luke 17:11-19). During the persecutions against the Church of Christ in Jerusalem some Christians fled there for protection (Acts 8:1). Jesus even sent his witnesses among the Samaritans (Acts 1:8). Jesus is not interested in what one is but on what one will become.

\section{Theological Reflections}

Jesus knew very well that the truth that will lead us to salvation is with us, what we generally lack is proper reflection and acting according to that reflection. We all have deep rooted ignorance. The story of the rich man and Lazarus reveals to us that the man made the mistake of the century by not making use of his God - given wealth to secure heaven for himself (Luke 16:20-31). The lawyer who wanted to test Jesus out of ignorance never knew that the table would turn against him. Jesus threw the question back to him by saying to him "look at the phylactery on your own wrist and it will answer your question. ${ }^{, 20}$ For strict orthodox Jews wore round their wrists little leather boxes called phylacteries, which contained certain passages of scripture Exod 13:1-10; 11-16; Deut. 6:4-9; 11:13-20; Lev. 19:18. The lawyer already had this material with him but he was culturally and spiritually blind. He could not see neighbourliness beyond members of his own sect. For him and all his brothers and sisters at their worst and their narrowest they confined the word neighbour to their fellow Jews. His question was genuine for he really did not understand. The Jewish Rabbis even sometimes helped to compound the problem by telling people that, "It is illegal to help a Gentile woman in her sorest time, the time of

\footnotetext{
${ }^{20}$ Barclay, W. (1975). 140.
} 
child birth, for that could only have been to bring another Gentile into the world."21 Some say, acceptance of alms by a Jew from a Samaritan delays the redemption of Israel. Also a maxim emerged that no Jew need trouble himself to save a Samaritan life. $^{22}$

Jesus shattered the worldviews and values of his hearers. He made the despised Samaritan the hero of the parable and made the so-called holy men (priest and Levite) the Villains. He really made the seemingly bad to be the really good and the seemingly good in the eyes of men to be the really bad. Jesus' career in that parable is not really to instruct but rather to challenge, to provoke, to shatter stereotypes ${ }^{23}$. Our norms for judging people are shattered and changed, unselfishness takes over from selfish motives, he gave his hearers the standard of judgment that is based on love.

So this parable deals primarily with the meaning of the commandment to love one's neighbour. Jesus points out to all that any person of any nation, who is in need of any kind, is our neighbour. Our help must be as wide as God's love. We have to realize the dictum, "Action speaks louder than words." One should not just feel sorry for the needy; something has to be done positively and practically. Never go about weighing the careless of the one in need before you can help him or her. Jesus was just telling them to help as much as they could. Jesus was also reminding them to be good, and that their goodness will also save them. One should never consider himself/herself and his/her ethnic environment to be more important and exalted

\footnotetext{
"'Barclay, W. (1975). 140.

${ }^{22}$ Talbert, C. T. (1982). Reading Luke, A Literary and Theological Commentary on the Third Gospel, 123.

${ }^{23}$ Talbert, C. T. (1982), 123.
} 
than others'. Finally one should avoid passing discriminatory remarks about others for one never knows what God is thinking about himself or herself and those people.

\section{Nigerian Multi-Cultural Context}

Nigeria is dominantly inhabited by the Hausa / Fulani, the Yoruba, and Igbos. Nigeria has three main regions, Northern, Western and Eastern regions. Each region has her own cousin minorities. They have respective common language, religion, culture and worldviews. It is the relationship between ethnic groups in a given polity that produces ethnicity. Sometimes if not all the times, each ethnic group looks at her culture, language and religion even their worldview as being of superior stock to that of others. If we look at ethnicity from the point of view of the fact that God put us in this world within different people and cultures without negotiating with us, just out of his own free will, then ethnicity is not evil but God-given. Scholars say that the problem with Nigeria seems really to be with ethnocentrism.

This is the belief in the superiority of one's own cultural group or society and corresponding dislike or misunderstanding on other groups. It is a malaise that makes us evaluate other races and culture by criteria specific to our own race, or ethnic group. It conditions us to see everything wrong with people of other tribes and race or ethnic group and everything right with ours. ${ }^{24}$

\footnotetext{
${ }^{24}$ Gotan C. T. (2004). "Leadership and Ethnicity: The Samaritan as a Model" in Ferdinand Nwaigbo et al, Ethnicity and Christian Leadership in West Africa SubRegion, Theology Week proceedings, CIWA Pub PH, 29 March - 1 April 2004, 28.
} 
Identification Of A Neighbour (luke 10:25-37)In Nigerian...

This prejudice and cultural bias are what parents pass on to thei children and it enters into the veins and arteries of our futur leaders. The application of learned prejudice against othe groups in our multi-ethnic society is an evil that has plague Nigerian nation from making any meaningful progress.

Ethnocentrism affects everything we do in this country Even our colonial masters used it against us in their principle 0 "divide and rule". Even they infused it into the blood stream o Fulanis that they are the only tribe in Nigeria with bes leadership qualities. The Hausa/Fulanis accepted this witl every impunity that they were never ready to listen to the yearnings of other ethnic groups in their aspiration to become the Nigerian number one citizen. ${ }^{25}$ Most students of the African political science agree on the fact that both ethnicity and religion are the most dangerous threats to the attainment of democracy in Africa. Sometimes the blindness associated with ethnocentrism has landed this great country in a situation of near disintegration. We have experienced ugly effects of massacres from clannish, ethnic, or sectional reasons. We lost nearly one million people in the 1967-1970 civil wars. In the last twelve years, we have also lost tens of thousands of lives in the Ife/Modakeke crisis, the Aguleri/Umuleri crisis, the Tiv/Jukun Crisis, the Egburu/Bassa Crisis, the Ijaw/Urhobo crisis and lately this Langtang/Wuse crisis in the Plateau. ${ }^{26}$ The one that is still with us today is the so called Boko Haram insurgence in the North that rendered millions of Nigerians homeless.

The bad influences both from the colonial masters and that of circumstances have made the Northerners to inscribe in

${ }^{2}$ Cf. Hassan, Kukah, M. (1999) Democracy and Civil Society in Nigeria, Ibadan: Spectrum Books Limited, 41.

${ }^{26}$ Gotan, Cletus, T. (2004). "Leadership and ethnicity: The Samaritan as a Model" 31. 
their plate numbers 'born to rule'. In 1986, a Sokoto prince, Alhaji Shehu Malami, in a speech to the youth corps members posted to Sokoto State, reminded his listeners of the ethnic superiority of the Hausa race which he says, "Had acquired their dark skins from intermarriages with the social African populations." ${ }^{27}$ To re-echo the above facts, in 1995, Alhaji Maitama Sule, one of Nigerian's respected bureaucrats, created another storm among Southern intellectual when he said, "Various communities in Nigeria were variously endowed: the Fulani with leadership qualities, the Igbo with industry and the Yoruba with diplomatic skills. ${ }^{28}$ Rev Fr. Hassan Kuka even toed the same line of argument when in a newspaper interview he told a reporter that "Nigeria would be a great country if it built on some of its complex qualities, "The dignity of the Fulani, the industry of the Igbo and the extravagant sense of celebration of the Yoruba." 29

Some erudite thinkers have even sat down and calculated how this country has been ruled from 1960 till date, and hence discover marginalization and subjugation of one or two ethnic group(s) with one always claiming superiority. According to available records, it is clear that while the North has ruled for 35 years, the West 11 years and six months, South has ruled three years and few months while Igbos has ruled for six months only. ${ }^{30}$

Even Wada Nas in his attempt to capture the domineering attitude of the North asked them to be merciful to Igbos when he said, "It is high time we allowed Igbos to taste power in this

\footnotetext{
${ }^{27}$ Hassan Kukah, M. (1999). Democracy and Civil Society in Nigeria, 98.

${ }^{28}$ Hassan, Kuka M. (1999).

${ }^{29}$ Hassan, Kuka M.(1996) "Interview" in The Guardian Newspaper, 18th Feb., 1996.

${ }^{30}$ Richardson Edward (2005) Heroes of New Biafra, Atlanta Georgia: Ivory Publishing 33.
} 
country... The Northern people are indebted to the Igbos."

This "being marginalized", and "born to rule" mentalit has become the easiest weapon our politicians use in thei various campaigns. All the argument of an Igbo man is that "I an a hated race and that there is collusion between West and Nortl against me." Even among Igbos, there is also bickering betweer the Igbos in Anambra and Imo state as well as Enugu and Umuahia. The same spirit is also seen among the Hausas and Yorubas. The annulment of June 12, 1993 presidential electior also gave the Yorubas the idea that they are a marginalized grour in Nigeria too. The coming of Obasanjo to power made some of them to feel compensated.

One can rightly say that there is a mutual suspicion among all the ethnic groups in Nigeria and even among ethnic groups. The first question they ask before any election is: "that candidate is from where? Before they ask - what are his capabilities? The above picture can be seen as the same situation that exists between the Semites especially Jews and Samaritans. Can Hausa man or woman help an Igbo man or woman who is in need? Or Igbo man or woman help Yoruba man or woman who is in need, or Ibibio man or woman helps an Ogoni man or woman who is in need? etc. In fact, can any Nigerian help another Nigerian who is in need no matter from where that Nigerian comes from?

\footnotetext{
${ }^{31}$ Wada, Nas "North Owes the Igbos" in the Interview Granted to Tell Magazine no. 44 Nov. 1. 2004.
} 


\section{Recommendations:}

\section{Change of Attitude}

We must remove the dark glasses on our eyes with which we view others negatively. We must remove the old yoke that justifies us and makes others stupid. Superiority based on ethnic background should be shunned. For we should understand that ethnicity, height, and language are not in the definition of a person, let there be renewal of attitudes. Even in the church, the presence of tribal sentiments and loyalty to one's ethnic group must be seen as a scandal of highest proportion hence should be viewed negatively. Before one relates with anybody, one must ask: can this bring out love and brotherhood in the world? Christ should be looked at as our model for it is only then would our negative view about people could change. This change of attitude, does not in any way ask us to forget our ethnic group rather, if one sees himself or herself in a better position, then one should make sure that the needs of other groups are taken care of. Let us encourage reconciliation and true communion between ethnic groups, favouring solidarity and unity of purpose. As far as politics is involved, there should be no undue ethnic consideration or favouritism.

\section{Recognition of our Multi-Cultural Diversity}

There is no denying the fact that Nigeria is a multicultural state, and within these cultural states we have various natural resources. It is very clear that Nigerian soil has crude oil, coal, tin ore, gold, lead, precious stone etc, and some zones are noted for certain crops and food items in large quantities yam, rice, ground nut pyramid, cocoa, palm oil etc. In order to get all we need, we have to be objective in citing the required machineries in the areas where we have these natural resources. This will enable us to avoid much of economic wastages we experience as a result of avoidable accidents. For instance, 
having refineries built around South-South where we have crude oil in large quantities instead of wasting our limited resources trying to transfer it to another area for refining. What is the motive behind the movement of capital of Nigeria from Lagos to Abuja? Why the transfer of all the ministries to Abuja? Now that we have International Airport now at Enugu, it will be wise also if we have all the Embassies located at that same Enugu as well so as to reduce the sufferings of other parts of the nation while struggling to get Visa. If our ethnic sentiments are removed and if right cord is tuned, this country will really be a habitable place for all. So let us appreciate ourselves and all our ethnic groups and what they can contribute to the common good.

\section{Appreciating Our Common Humanity}

We are all created equal by God; male and female he made us (Gen 1:27). No one is more of the image and likeness of God than the other (Gen 1:26). There should be mutual respect. Hence there should be justice for all. If we are all equal before God, then we have to uphold the scriptural imperative of love of God and neighbour. When one looks at the parable under discussion, one will realize that the lawyer may have chosen not to call the Samaritan by name in verse 37 to avoid actually naming the despised Samaritan. We should know that the giving and receiving of mercy transcends national and racial barriers. It is left for us to put this into practice. With authority, Jesus commanded the lawyer to go away and begin to follow the Samaritan's example; the command in verses 28 and $37 \mathrm{~b}$ cannot be avoided. It is wrong to interpret "klesion" (neighbour) in terms of the members of the same people, and religious community (cf. Matt 5:43-48). We have to appreciate our common humanity as the Samaritan did.

\section{Conclusion}


The story of the Good Samaritan as related in Luke 10:30-35 is simple and conveys a clear lesson. It contrasts the lack of compassion shown by two members of the Jewish priesthood towards an unknown and unfortunate sufferer with the obedience to the law shown in practical compassion by (in Jewish eyes) the most unlikely of person, a Samaritan. Let us reiterate that the great challenge before us all is this: if there is to be a regeneration of the national character, it can come about only by the regeneration of each of us as individuals. It can only come about from subtle change in the heart of the individual men and women. Let the ministers of God be very careful lest they turn out to be agents of division in the church. Our embrace should not be superficial but from the heart. Transparency in action is one of the things we need sincerely to make a meaningful progress in this country. Finally, any culture that is not humanity oriented is not Christological and hence should be abhorred in all its ramifications. Any culture that tends to divide humanity is yet to encounter Christ. The priest and the Levite of our parable are still living in the ancient culture of divisiveness and so was the Lawyer that asked the question that gave us the parable. It is very clear from the above expositions that a right understanding of "a neighbour" will enhance our life here on earth especially our life here in Nigeria. 